\title{
Physico-chemical and Bacteriological Survey of Household Water Supplies in Selected Communities in Anambra State, Nigeria
}

\author{
C. O. Nwajinka, E. C. Nwanna, K. N. Ogbu* \\ Department of Agricultural \& Bioresources Engineering, Nnamdi Azikiwe University \\ Awka, Nigeria \\ "Corresponding author's email: kn.ogbu [AT] unzik.edu.ng
}

\begin{abstract}
Physico-chemical and bacteriological characteristics of borehole water in seven communities in Anambra State were investigated to ascertain their portability and evaluate their pollution levels for household consumption. Obtained sample results were compared with threshold values reported by World Health Organization (WHO) for drinking water purposes. Study results show that values for total hardness, lead, copper, zinc, iron and coliform count exceeded the WHO thresholds and as such made this resource unfit for human consumption. It is recommended that the state water board be revamped and its branches established in all communities of the state to ensure regulation and control of the water household water supplies.
\end{abstract}

\section{INTRODUCTION}

Half of global human population lack access to portable water notwithstanding that fact that water covers about $71 \%$ of the earth's surface (Kelmendi et al., 2018). Poor access to clean water and poor sanitation especially in developing nations have resulted to wide outbreak of water-related diseases (Duressa et al., 2019). Consequently, about $88 \%$ of diarrhea cases globally, are caused by poor water quality (Muhammed et al., 2016). TWAS (2002) reported that about six million deaths in developing countries are recorded daily due to water-related diseases. The importance of improving water quality as a way of reducing poverty is a major goal in the 2030 agenda for sustainable development adopted by United Nations. However, population growth, industrial and domestic effluent contamination of water sources and poor sanitation has greatly hampered efforts to deliver portable water to households (Duressa et al., 2019).

Surface water resources are undoubtedly exposed to impacts from anthropogenic activities and are easily polluted than groundwater sources. In developing countries, there is little concern on the quality of groundwater as it is believed to have been purified through active microbial processes and filtrations. However, shallow wells are also easily contaminated through pollutant seepage. Also, well casings and in most cases, casing sealants can contaminate water supplied to households from ground water sources.

The problem of community water supply is common to most developing countries around the world, despite its importance in meeting the needs of their ever-increasing population. According to Ezenwaji (2014), even with increased effort in water supply to both urban and rural areas in Nigeria over the years, it is doubtful that the country will meet the millennium development goals target of ensuring that half the population of Nigeria have improved water sources. Though there is improvement in water supply, records have it that up to 63 million Nigerians still lacks access to improved water supply (Obinna, 2014). As a result, many Nigerians are still exposed to high rates of water diseases such as cholera, diarrheal, dysentery and other such diseases arising from the consumption of unsafe drinking water (Mohammed, 2007; Obeta, 2003).

The major sources of water supply in Nigeria are predominantly streams and boreholes in the rural and urban areas respectively. However these sources, in most places, lack reliability. In places inhabited by lower income groups there are little or no public water services which in some cases are usually of questionable quality. Therefore, a good percentage of the residents of these low income areas augment their water needs with that obtained from water vendors whose sources of water are not known.

In Anambra State, hand dug wells and boreholes are heavily relied on for water supply to households due to degradation of surface water sources and failure of government to provide good quality water for her citizens. However, poor well construction using cheap materials and location of boreholes close to contaminant sources have affected the quality of this resource with impacts on human health (Saidu and Gimba, 2019). In this study, therefore, the quality of borehole water in some towns and municipalities of Anambra state was investigated to address the contending issues of domestic water supply in the state. Based on the foregoing, the need for this study is critical in planning for water supply infrastructure in Anambra State. 


\section{STUDY AREA}

Anambra State (Fig. 1) is located in the South-Eastern part of Federal Republic of Nigeria, between Latitudes $5^{\circ} 45^{\prime}$ and $6^{\circ} 46^{\prime} \mathrm{N}$ and Longitude $6^{\circ} 31 \mathrm{E}^{\prime}$ and $7^{\circ} 03{ }^{\prime} \mathrm{E}$ and covers an estimated land area of $4887 \mathrm{~km}^{2}$. Anambra state has a tropical climate with annual average temperature and rainfall of $27^{\circ} \mathrm{C}$ and $1828 \mathrm{~mm}$ respectively. According to the last population census of 2016, the state has a projected population of about 5,527,800. Seven Local Government Areas (LGAs) (Fig. 1) were selected for this study, covering the three senatorial districts in the state. Two LGAs each were randomly selected from each senatorial zone and Awka, which is the state capital for this study. The local governments selected are Aguata, Anaocha, Awka North, Awka South, Onitsha North, Onitsha South and Orumba South.

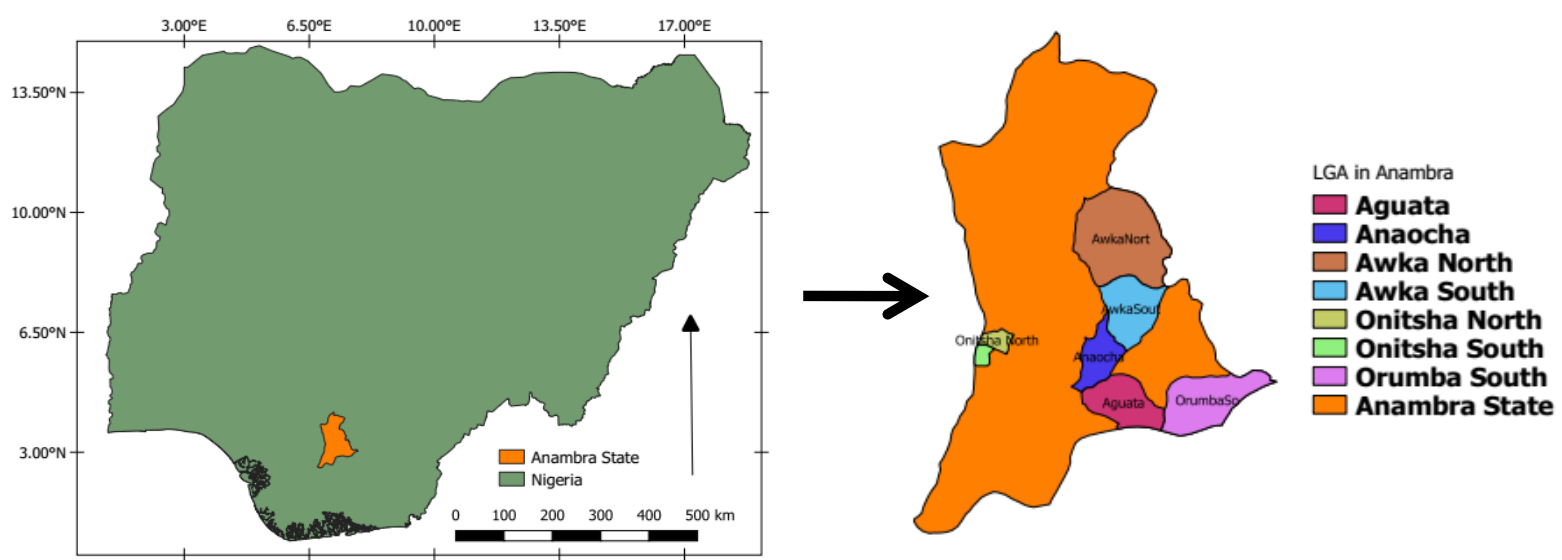

Fig. 1: Map of the Study Area

\section{MATERIAL AND METHOD}

Water samples for physico-chemical and Microbiological analyses were randomly collected from household boreholes in triplicates in seven (7) communities in Annambra State namely: Aguata, Anaocha, Awka North, Awka South, Onitsha North, Onitsha South and Orumba South and transported to the Department of Microbiology Laboratory, Nnamdi Azikiwe University, Awka for analyses. The sampling process was carried out both in rainy season (July) and dry season (December) for all the communities considered with the aim of assessing the quality of these water sources for human consumption. The water quality parameters analyzed are: temperature $\left({ }^{\circ} \mathrm{C}\right), \mathrm{pH}$, total dissolved solids $(\mathrm{mg} / \mathrm{l})$, total hardness $(\mathrm{mg} / \mathrm{l})$, chloride (mg/l), lead (mg/l), copper (mg/l), zinc (mg/l), sodium (mg/l), iron (mg/l), nitrate (mg/l), sulphate (mg/l) and total coliform (cfu/100 ml).

Water samples for microbiological analyses were collected using $250 \mathrm{ml}$ sampling screw-capped sterilized bottles while 4-litre plastic containers with screw caps were used for samples meant for physico-chemical analysis. Sampling methods for both physic-chemical and microbiologic analyses were done according to the American Public Health Association procedures (APHA, 2005). These samples were placed inside ice-chests to maintain temperature of water samples during transportation for laboratory analysis. Samples were analyzed within twenty-four (24) hours of its collection but where analyses were delayed, samples were refrigerated at $4^{\circ} \mathrm{C}$. All glass wares used for the collection of water samples were sterilized in an autoclave at $120^{\circ} \mathrm{C}$ for 15 minutes.

Data collected after laboratory analyses were subjected to statistical analysis using t-test to determine if there are significant differences between the true mean $(\mu)$ of the parameters in each season and the thresholds recommended by World Health Organization (WHO). Laboratory parameters values were also compared with drinking water quality limits as recommended by World Health Organization (WHO 2011).

\section{RESULTS AND DISCUSSION}

Results of the one sample t-test to determine if statistical significant differences exist between means of water quality parameter sampled for both seasons, and for rainy and dry season from WHO standard at 95\% confidence level are shown in Table 1. The graphs of the analyses to determine the seasonal mean values of parameters in comparison with WHO thresholds are shown in Figs. 2 to 14. 
Table 1: T-statistics of Water Quality Parameters in Different Seasons

\begin{tabular}{llll}
\hline Parameters & $\begin{array}{l}\text { t-value for dry and rainy } \\
\text { seasons }\end{array}$
\end{tabular}

\begin{tabular}{llll}
\hline Temperature & $19.0^{*}$ & $12.7^{*}$ & $13.8^{*}$ \\
pH & $3.2^{*}$ & 0.6 & $3.7^{*}$ \\
TDS & -103.4 & -71.8 & -72.6 \\
Total hardness & 0.03 & 0.4 & -0.3 \\
\hline Chloride & -302.7 & -736.7 & -176.6 \\
\hline Lead & $6.3^{*}$ & $5.9^{*}$ & $3.7^{*}$ \\
\hline Copper & $2.6^{*}$ & $2.09^{*}$ & 1.6 \\
Zinc & 1.5 & 0.7 & 1.3 \\
\hline Sodium & -714.8 & -506.7 & -508.3 \\
Iron & $11.3^{*}$ & $11.0^{*}$ & $7.0^{*}$ \\
\hline Nitrate & -5049.9 & -3194.9 & -4211.4 \\
\hline Sulphate & -4906.7 & -3262.1 & -3660.3 \\
\hline Total coliform & $10.5^{*}$ & $8.5^{*}$ & $12.2^{*}$ \\
\hline *ignificant at $95 \%$ confidence level & &
\end{tabular}

*significant at $95 \%$ confidence level

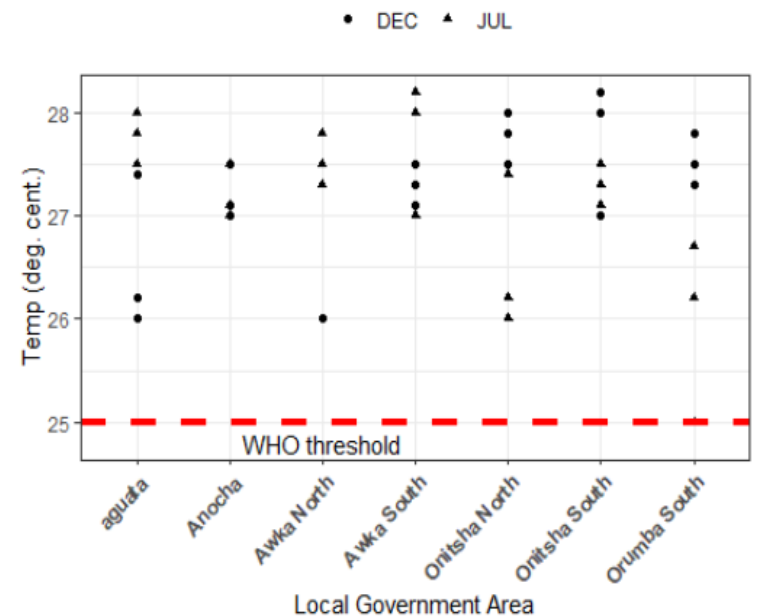

Fig. 2: Temperature of the water samples

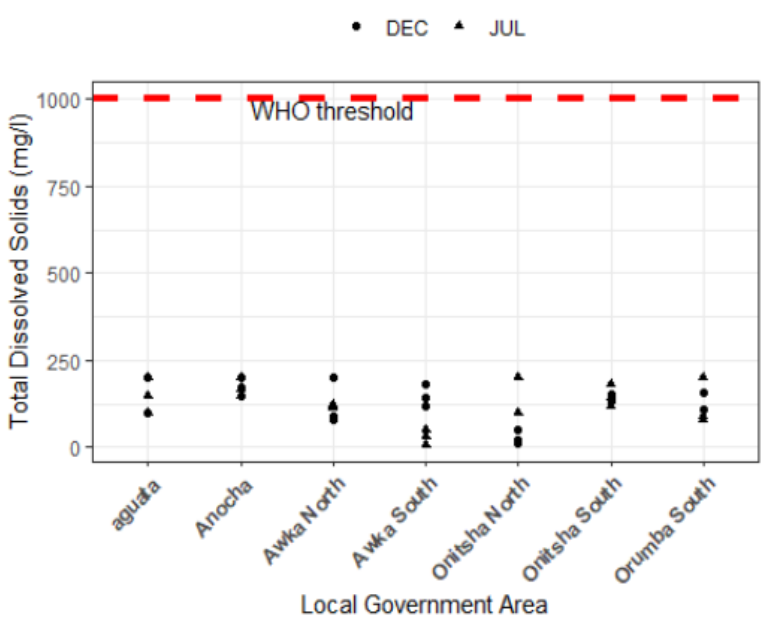

Fig. 3: TDS of the water samples

- DEC \& JUL

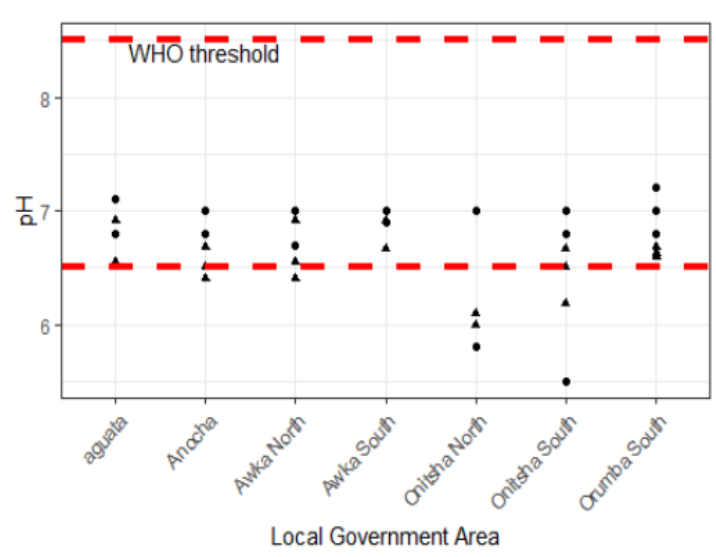

Fig. 4: $\mathrm{pH}$ of the water samples 


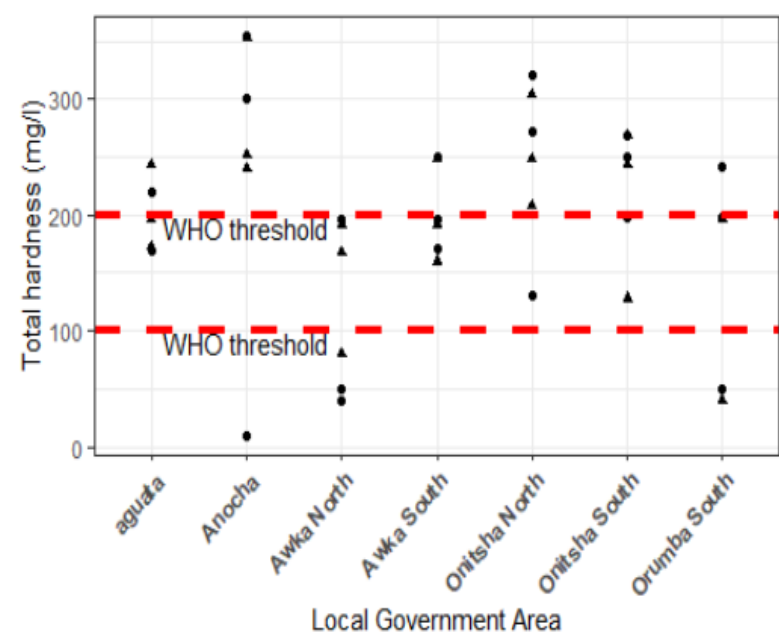

Fig. 5: Total Hardness of the water samples

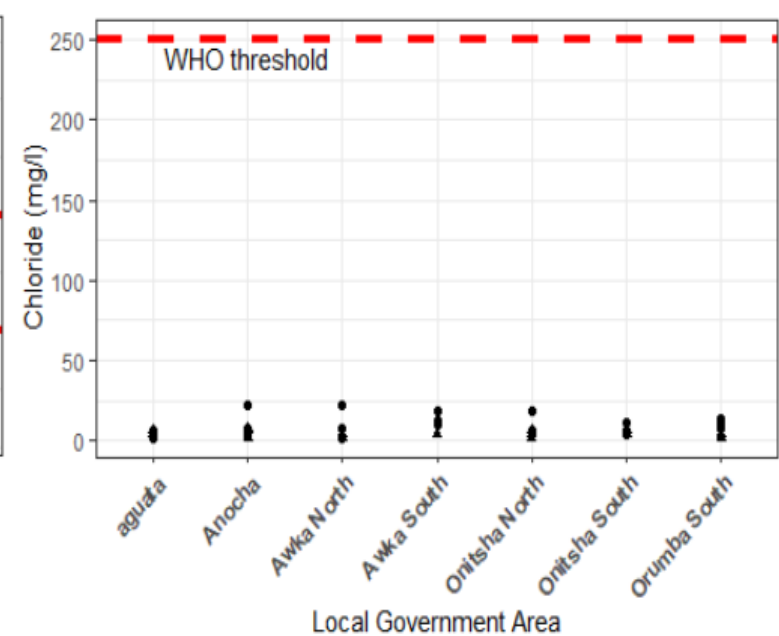

Fig. 6: Chloride content of the water samples

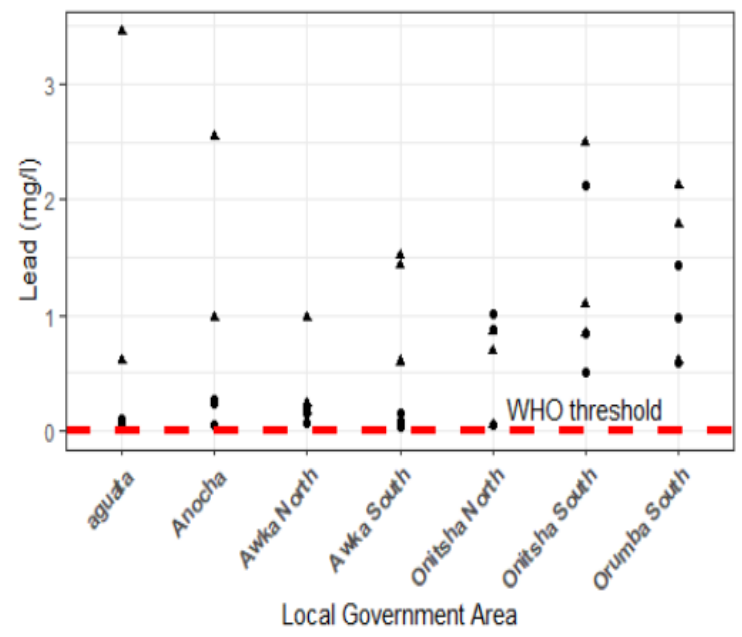

Fig. 7: Lead content of the water samples

- DEC * JUL

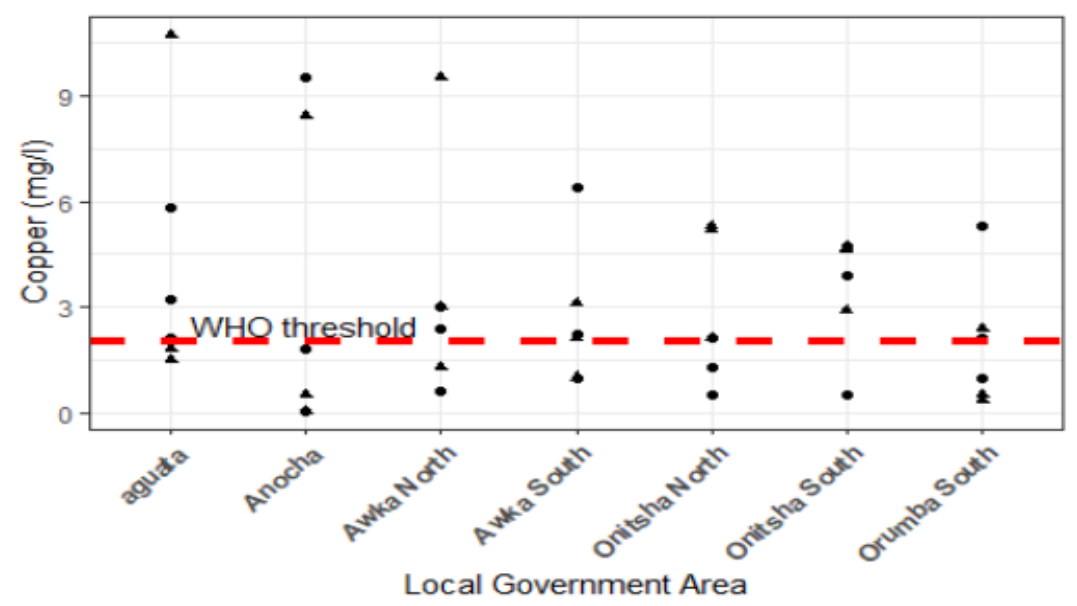

Fig. 8: Copper content of the water samples 
- dec * Jul

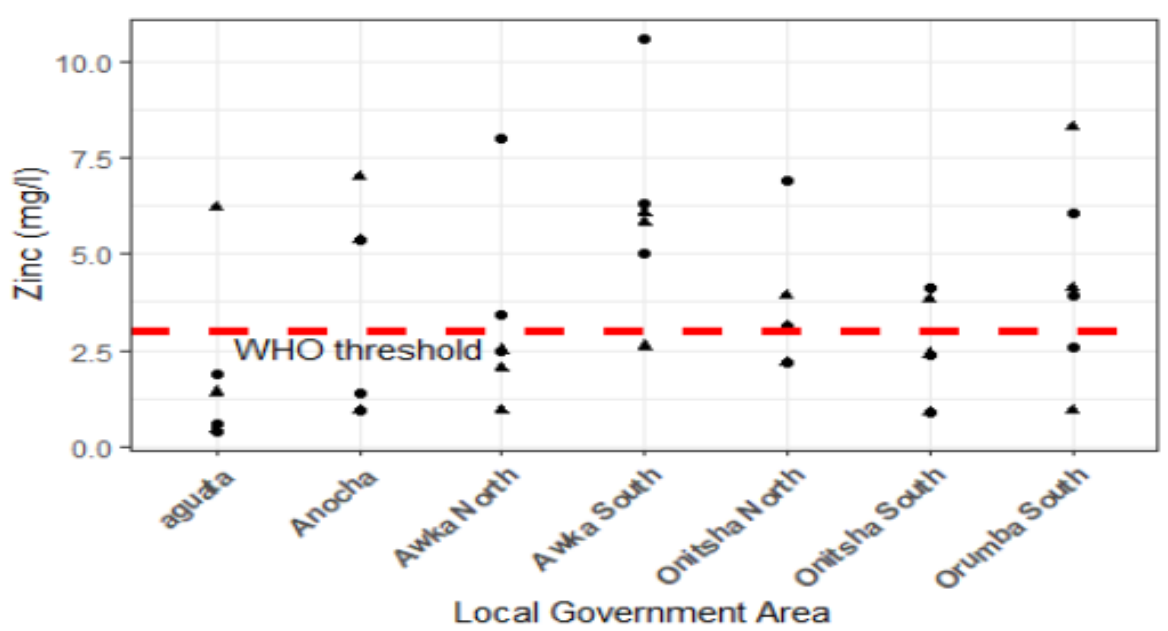

Fig. 9: Zinc content of the water samples

- DEC * JUL

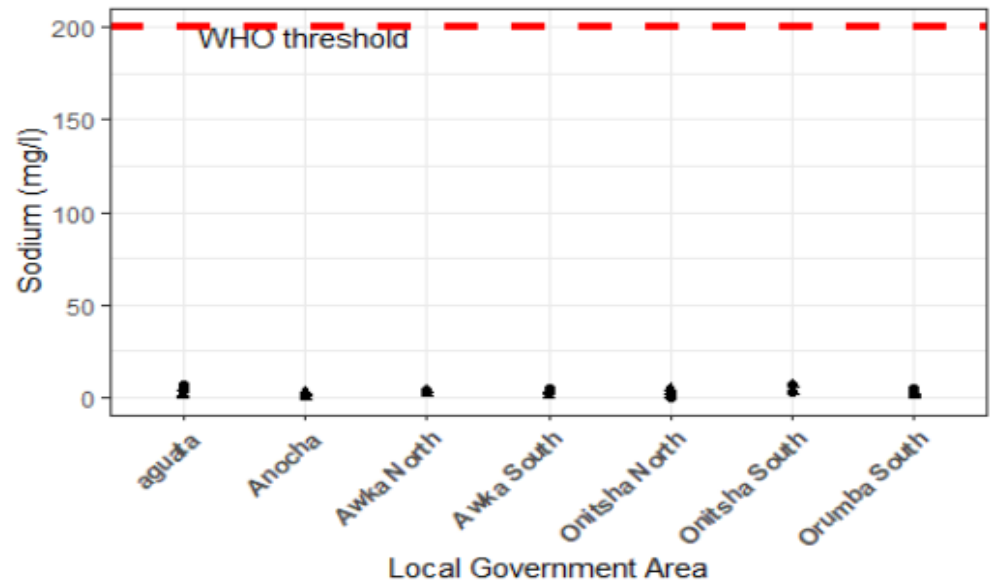

Fig. 10: Sodium content of the water samples - DEC ^ JUL

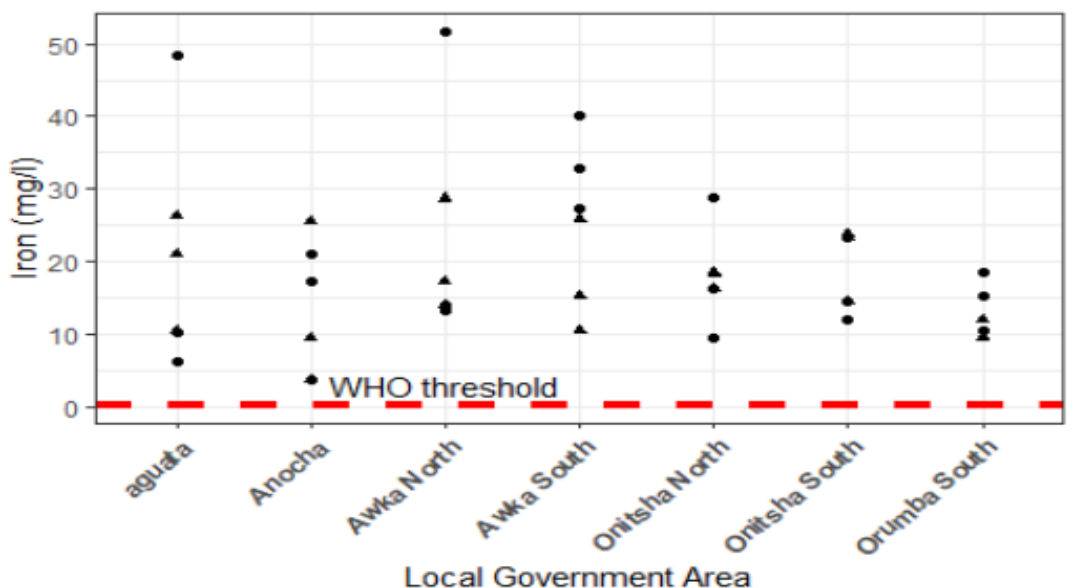

Fig. 11: Iron content of the water samples 
- DEC * JUL

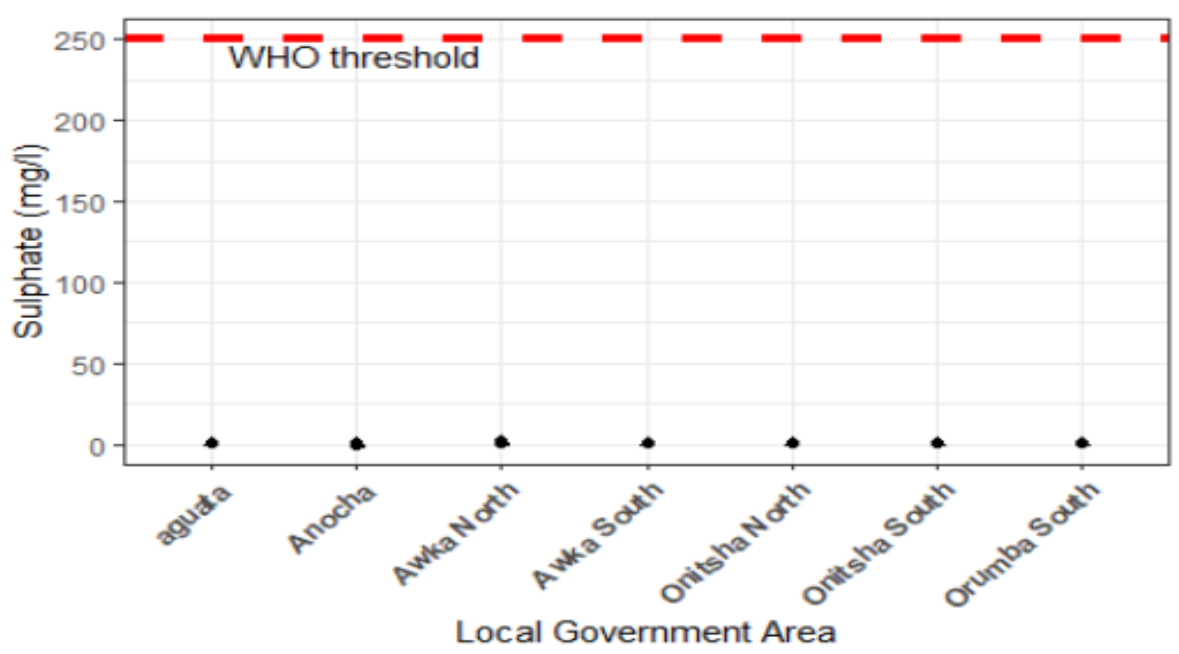

Fig. 12: Sulphate content of the water samples

- DEC * JUL

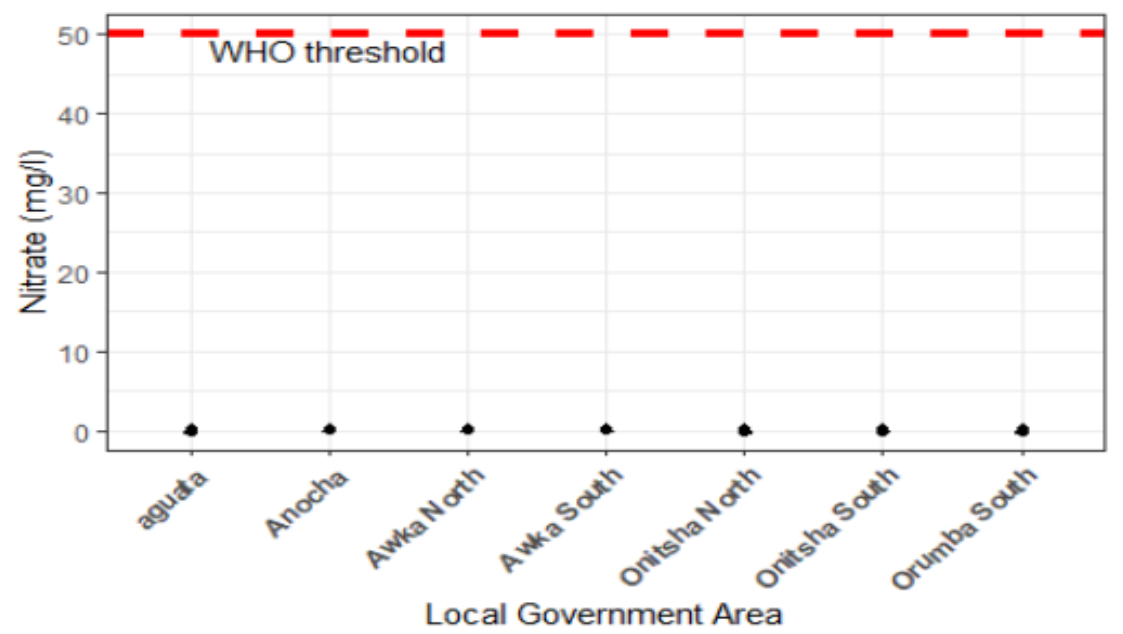

Fig. 13: Nitrate content of the water samples

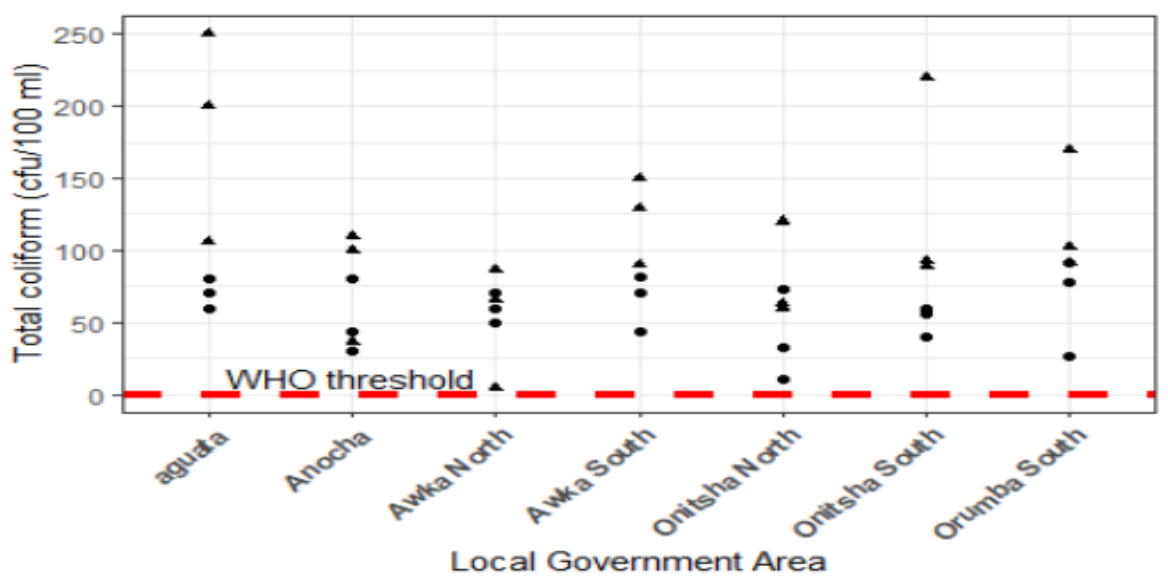

Fig. 14: Total coliform 
The temperatures of water samples for all sampled locations and for both seasons were all higher than the WHO threshold as shown in Fig. 2. These values could be attributed to the climatic conditions of the area which lies in the tropical region. High water temperature enhances the growth of microorangism and can cause odour, taste and colour problems. T-test statistics (Table 1) also showed that the mean temperature for both seasons differs significantly from the WHO threshold.

Total dissolved solid (TDS) for all sampled locations as presented in Fig. 3 show values lower than the threshold level as stipulated in WHO (2010). Samples for both season showed the water source to be devoid of dissolved solids in levels that threaten human lives. These low values could be attributed to the effect of filtration by overlaying soil layers during rainfall infiltration. T-test results (Table 1)also showed that no significant difference exist between mean values and WHO standard.

$\mathrm{pH}$ values of borehole water samples for all communities ranged from $6.1-7.2$ for both seasons with samples collected at Anaocha, Awka North, Onitsha North and Onitsha South falling below WHO standard threshold (WHO, 2011) for drinking water as shown in Fig. 4. This could mean that such water are corrosive and will affect piping system materials for delivering water from wells to households. Table 1 also shows that there exist significant differences between means of $\mathrm{pH}$ values for dry season and both seasons, from the WHO threshold.

Hardness of water may be caused by high levels of Calcium $\left(\mathrm{Ca}^{2+}\right)$ or magnesium $\left(\mathrm{Mg}^{2+}\right)$ cation present in water samples (Ugbaja and Ephraim, 2019). Total hardness values for sampled locations varies from 10 - $354 \mathrm{mg} / \mathrm{l}$ with all communities showing values below and above the stated thresholds $(100-200 \mathrm{mg} / \mathrm{l})$ for both seasons as shown in Fig. 5. This could result to deposition of scales in piping systems and high soap consumption during water use for domestic cleaning (WHO, 2011).

High concentration of chlorides in groundwater could be as a result of surface/subsurface geology or from runoffs laden with de-icing salts (Kelmendi et al., 2018). The chloride content of all water samples shown in Fig. 6 fell below the WHO permissible limit for drinking water. Tamar et al. (1999) states that chlorides are not harmful to humans but at certain high concentration impacts taste and could cause corrosion.

Fig. 7 show that all sampled water contains high concentration of lead above WHO (2011) permissible limit of $0.1 \mathrm{mg} / \mathrm{l}$ and are not recommended for human consumption. Presence of lead in these water samples might have come from piping system and water reservoirs materials (PVC and metal materials). Lead is an accumulate poison which is stored in the bone and causes irreversible nervous damage when ingested by human beings.

Copper ion content for most of the water samples were above WHO permissible limit as shown in Fig. 8. Samples from Aguata, Anaocha and Awka North gave very high values above $6 \mathrm{mg} / \mathrm{l}$ for both seasons. The occurrence of copper in borehole water may be as a result of dissolution of copper bearing materials directly into water sources or underground deposits of the ore through which the boreholes were drilled (Prescott et al., 1999). All the water samples tested showed values that are significantly above the WHO permissible limit for some households and are not recommended for human consumption.

Most of the samples for all the communities tested for zinc showed high concentrations well above the permissible limits as recommended by WHO (Fig. 9). This could be attributed to dissolution of zinc from water distribution pipes and as such has affected the quality of water consumed by households.

Sodium content (Fig. 10) of all the water samples was below the WHO permissible limits and does not pose danger to human consumption.

The Iron content in all the water samples (Fig. 11) were above WHO permissible limits which could be as a result of dissolution of iron in the water emanating from indiscriminate disposal of ferrous materials generated by local metal and auto-mechanic industries which are sited in all the communities.

The sulphate content in all the water samples was low from $0.02-1.7 \mathrm{mg} / \mathrm{l}$ as shown in Fig. 12, and all were below the WHO permissible limits for drinking water, showing that it is recommended for human consumption.

The concentrations of nitrate for all sampled locations ranged from $0.02-0.19 \mathrm{mg} / \mathrm{l}$ and are below the WHO permissible level (Fig. 13) and as such are recommended for human consumption.

Presence of bacteria was seen in all the water samples for both seasons in all sampled water. Fig. 14 shows that all samples had bacterial count above WHO permissible limit for drinking water purposes. E.coli, Staphylococcus aureus, Streptococcus faecalis, Salmonella typhi, Clostridium perfringes were identified in all samples. Several factors can cause this such as human and animal feces deposited in surface flows or siting of boreholes close to septic tanks. High bacteria 
counts in water samples implied that majority of the water samples were faecally polluted from seepage of septic tanks/latrines, household waste, improper boreholes construction, failure to seal abandoned boreholes and human activities near the boreholes. The presence of pathogenic bacteria in the water samples constitute health hazard since WHO recommended that the presence of coliform bacteria in every $100 \mathrm{ml}$ of the water samples pose high risks to human health. All the water samples were heavily polluted when compared to WHO standards and are not fit for drinking without treatment. Some form of treatments is strongly recommended before the water from the boreholes is served as table water, but that is not the case as observed in the study area.

The state water board collapsed and there were no state operated public water scheme, which leaves the responsibility water supplies in the hand of households without strict regulations and control. Among the sources of domestic water available in the state, the most viable and reliable, in relative quality terms, is borehole water (underground water) since surface water is heavily polluted by poor waste management in most areas of the state. Consequently, the number of boreholes is increasing without corresponding implementation of regulatory actions to ensure compliance to the standard practice and conditions for approval. The borehole industry has become all comers business, making the product of this enterprise threats to life of the consumers; a situation where once water is drawn from the borehole, no test is conducted before it is set for distribution and consumption.

\section{CONCLUSION}

In this study, household water supplies in seven communities were analyzed to ascertain its portability for drinking purposes. Result showed high concentrations of total hardness, lead, copper, zinc, iron well above permissible limit recommended by WHO thereby making it unfit for human consumption without treatment. Microbiological analyses showed that all the boreholes are contaminated with high level of bacteria and are above permissible levels recommended by WHO. Generally, results show that water supplies to households in sampled locations do not undergo any form of treatment and is a major cause of high waterborne disease in this region.

Good quality water should be free from pathogens, poisonous substance and excessive amount of organic matter. This study recommends that a comprehensive legislative work be carried out on this critical sector and infrastructure development improved to deliver good quality water to households.

\section{ACKNOWLEDGEMENT}

This research was funded from the 2016/17 (merged) Tertiary Education Trust Fund (TETFund) of Nnamdi Azikiwe University, Awka, Nigeria

\section{REFERENCES}

- APHA (2005). Standard Methods for the Examination of Water and Wastewater. 21st Edn., American Public Health Association/American Water Works Association, Washington, DC., USA.

- Ezenwaji, E.E., Awopeju, A.K., Otuti.v.i. Edupta, B.M. (2014). Spatial Patterns of Residential Water Supply Accessibility Levels in Anambra State, Nigeria. Journal of Engineering Research and Applications, 4(1): 326336.

- $\quad$ Kelmendi M., Kadriu S., Sadiku M., Aliu M., Sadriu E., Hyseni S.M. (2018). Assessment of Drinking Water Quality of Kopiliq Village in Skenderaj, Kosovo. Journal of Water and Land Development, 39: 61-65

- Mohammed, M. (2007). The Problem of Supplying Water of Doubtful Quality to Consumers in Jos, Nigeria. Journal of Tropical Sanitation, 3: 60-71.

- Muhammed, A.U., G. Nicolas, and V. B. Joachim (2016).e Impact of Drinking Water Quality and Sanitation Behavior on Child Health: Evidence from Rural Ethiopia, ZEF-Discussion Papers on Development Policy No. 221, Center for Development Research, Bonn, Germany

- Obinna, C. (2014). Nigeria May Miss MDGS Target for U.N.I.C.E.F Water, Sanitation. Vanguard Newspaper (8/8 2014). www.vanguardng.com.

- Saidu, M. A. and Gimba, B. E. (2019) Analysis of Physicochemical Parameters Of Selected Open-Wells In Southern Senatorial Zone Of Kaduna State, Nigeria. FUDMA Journal of Sciences, 3( 1):39 - 48

- $\quad$ Third World Academy of Sciences -TWAS (2002). Safe Drinking Water: The Need, The Problem, Solutions and an Action Plan. Report of the Third World Academy of Sciences. Third World Academy of Sciences, Trieste, Italy.

- WHO, 2010. World Health Organization Guideline for Drinking Water Quality. 3rd Edn., World Health Organization, Geneva, Switzerland. 